\title{
Recipe-technological aspects of improving the properties of non- autoclaved aerated concrete
}

\author{
Anatoliy Shuisky, ${ }^{1,}$, Sergey Stelmakh ${ }^{1}$, Evgeniy Shcherban ${ }^{1}$, and Elena Torlina ${ }^{1}$ \\ ${ }^{1}$ Construction and Architecture Academy at Don State Technical University, Rostov-on-Don, Russian Federation
}

\begin{abstract}
The paper dwells upon non-autoclaved aerated concrete technology issues relating to the effect of various composition and technological factors on the aerated-concrete non-autoclave products. It presents the results of experiments carried out to study the effect of three factors: the order in which components are added to the AC mixture; the efficiency of adding a complex sodium additive to the mixture; the effect of adding the structuring additive, the 'off-cut'. Comparative analysis of physico-mechanical test results revealed that adding the structuring additive increases the compression strength of aerated concrete while also making it denser.
\end{abstract}

\section{Introduction}

As of today, aerated concrete is popular in construction as an efficient heat insulation. Producing high-quality aerated concrete products is very relevant.

Aerated concrete is either a cement or lime mortar, classified as lightweight concrete, in which air-voids are entrapped in the mortar matrix by means of a suitable aerating agent. Broadly speaking aerated concrete falls into the group of cellular concrete (microporite being the other). The prominent advantage of aerated concrete is its lightweight, which economizes the design of supporting structures including the foundation and walls of lower floors. It provides a high degree of thermal insulation and considerable savings in material due to the porous structure. By appropriate method of production, aerated concrete with a wide range of densities can be obtained thereby offering flexibility in manufacturing products for specific applications (structural, partition and insulation grades). There have been several investigations on the properties of aerated concrete in the past.

Although aerated concrete was initially envisaged as an insulation material, there has been renewed interest on its structural characteristics in view of its lighter weight, savings in material and potential for large-scale utilization of wastes like pulverized fuel ash. Hence, it was felt essential to compile and review the available literature on aerated concrete. This review aims to classify the studies on aerated concrete related to its material structure and properties. Gas-forming chemicals are mixed into lime or cement mortar during the liquid or plastic stage, resulting in a mass of increased volume and when the gas escapes, leaves a porous structure. Aluminum powder, hydrogen peroxide/bleaching powder and calcium carbide liberate hydrogen, oxygen and acetylene, respectively. Among these, aluminum powder is the most commonly used aerating agent. Efficiency of aluminum powder process is influenced by its fineness, purity and alkalinity of cement, along with the means taken to prevent the escape of gas before hardening of mortar. In the case of Portland cements with low alkalinity, addition of sodium hydroxide or lime supplement the alkali required.

Aerated concrete can be non-autoclaved or autoclaved based on the method of curing. The compressive strength, drying shrinkage, absorption properties etc. directly depend on the method and duration of curing. The strength development is rather slow for moist-cured products. Autoclaving initiates reaction between lime and silica/alumina bearing ingredients.

Properties of concrete such as strength, permeability, diffusivity, shrinkage and creep are intimately related to its porosity and pore size distribution. Thus, the characterization of the pore structure is extremely important, and more so in the case of aerated concrete where the porosity may be as high as $80 \%$. Porosity and pore size distribution of aerated concrete varies considerably with the composition and method of curing [1].

Russian and foreign scientists have developed theories on the aerated concrete structuring processes as well as the basics of producing high-quality materials that have the necessary physico-mechanical properties and sufficient service life.

The important problem here consists in developing and organizing the production of pasty gassing agents for construction material industries. To this end, we have to identify the most efficient of theexisting gassing agents based on such criteria as reactionary capacities, technological versatility, and long-term storage under various conditions [2].

\footnotetext{
Corresponding author: rgsu tvvb@mail.ru
} 
The optimal aerated concrete structure is very and uniformly porous; cells are optimally distributed by size, while the defects of interporous partitions are minor to none.

Gassing kinetics induced by the agent as well as the changes in the rheological properties of the interporous material are crucial for the formation of the pore structure in aerated concrete $[3,4,5,6,7,8]$.

We paid particular attention to the kinetics of the rheological properties of the interporous materials as observed during the swelling of cellular-concrete mixtures [9, 10, 11, 12, 3, 13].

The interporous partitions in such an AC mixture is a complex kinetic system where the changes in rheological properties mostly depend on the structuring of the cement. Both Russian and non-Russian scientists have studied the structuring of concretes and cements: A.A. Baikov, Yu.M. Butt, P.P. Budnikov, R.L. Berger, S. Brunauer, A.V. Volzhensky, J. Verbeck, H. Le Chatelier, F. Lawrence, Yu.S. Malinin, V. Mikhaelis, O.P. Mchedlov-Petrosyan, V.B. Ratinov, I.N. Kruglitsky, L.A. Pashchenko, P.L. Rebinder, M.M. Sychev, V.V. Timashev, et al. When the cement is water-mixed (gauged), it triggers continuous and complex physicochemical transformations that occur in parallel with the dissolution, hydration, topochemical reactions, coagulations, crystallizations, etc. By measuring the intensity of these processes, we can adjust the rheological properties of the mixture at the various stages of cement curing, thus controlling the structure and properties of the cured material.

Swelling occurs when three intensively evolving processes - structuring of the cement and the interporous partitions, heat release, and gassing induced by the gassing agent-overlap. Slight variations in technological parameters result in drastic changes in the swelling kinetics, making the properties of concrete less stable. This assumption prejudges the search for solutions to eliminate these disadvantages.

Based on the achievements of physico-chemical mechanics, a branch founded by P.A. Rebinder, O.P. Mchedlov-Petrosyan worded the principles of controllable structuring induced by hydration curing; the most important principles are the quality of the original mixture component and the conditions under which it is prepared (homogenization, the time and intensity of mechanical impact).

Mixtures used in the production of aerated concrete should have low critical shear stress point while also having sufficiently high viscosity. This assumption is referred to when deciding how to control the aerated concrete structuring process $[14,12,15,16]$. One of the methods used to induce controllable changes in the rheological properties is to apply vibration and impact during the swelling $[9,17,16,18,12,3,15]$. Vibration with varying frequency and amplitude can change and stabilizing the swelling kinetics [3, 19]. However, vibration makes the entire process more energy-intensive while also producing considerable noise.

Another efficient method used to adjust the rheological properties of the mixture being swollen consists in adding surfactants and superplasticizers that lower the critical shear stress point $[14,11,20,13,21]$ and slow down the structuring process.

There are other ways to control the changes in aerated concrete structuring, including (i) use of raw materials based on coarse-ground sands [22, 23, 24, 25, 21], (ii) dispersive reinforcing by means of fibrous additives [26], (iii) modifying the structure by means of polymer additives $[27,28]$, etc.

In-depth analysis of how technological factors affect the properties of the AC mixture and the operating performance of such concrete, and the subsequent use of analytical data to control the structuring process is enabled by identifying the set of patterns in the physicochemical processing occurring in micro- and macrostructuring of aerated concrete; identifying the specifics of destructive processes occurring in aerated concrete at all the structuring phases; determining the criteria to evaluate the quality of the AC structure at swelling, with the structuring process being subsequently optimized based on such criteria; developing reliable methods and instruments to control and study the cellular-concrete mixture swelling phenomena.

\section{Experimental program and research results}

The Cementing Substance, Conrete, and Construction Ceramics Department of the Construction and Architecture Academy at Don State Technical University has carried out a series of experiments to study the presence and effect of various factors.

One of such factors is the order in which components are added to the mixture. In our studies, we assumed the basic component addition order that is used at an enterprise located in Rostov Oblast.

For this basic technology, water is dosed at $\mathrm{t}=45^{\circ} \mathrm{C}$ to the tank of the AX mixer; after the mixer is turned on, add sand, dry soda and sodium sulphate additives, and then cement. The components are mixed for four minutes upon gauging. Then the mixture is supplemented with aluminum suspension and mixed for another 20 seconds.

The experimental order was as follows: dose water to the mixer tank at $\mathrm{t}=45^{\circ} \mathrm{C}$ and switch on the mixer engine; then add soda and sodium sulfate and prepare the additive solution for 15 seconds; then add cement and mix the suspension for 30 seconds; then dose sand and mix for four minutes upon gauging; then doze aluminum suspension to the mixture and mix it for another 20 seconds.

We've made samples of the AC1 (factory-used) and AC3 (experimental) mixtures.

Those were compared on the following bases: average density, compression strength, and structural quality factor.

Figure 1 presents the results of AC sample tests taken after seven days of normal curing.

The results of $\mathrm{AC} 1$ and $\mathrm{AC} 3$ tests led us to the conclusion that the compression strength had increased 1.5 times while the structural quality factor had been 
almost doubled while the density increase was insignificant.

The results encouraged us to use the proposed component addition and AC mixture preparation procedure in further experiments.

The next factor affecting the quality of nonautoclaved concrete is the addition of the so-called offcut, the porous mixture pieces that are cut off after swelling is over and the necessary elastic strength is achieved.

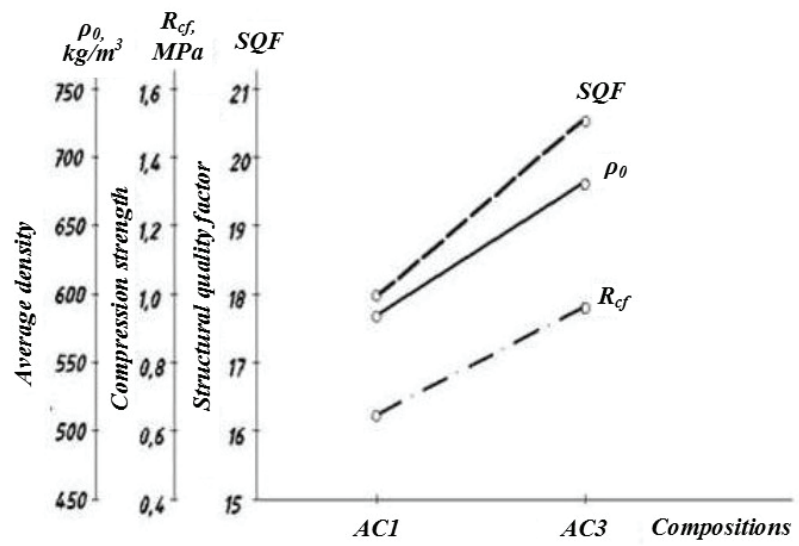

Fig. 1. Test results

When adding the off-cut to the AC mixture being prepared, hydrated cement grains should become the hydrate neoplasm crystallization centers to boost the AC structuring and curing process. In an experiment we carried out, sodium sulfate used at factories as the curing accelerator was replaced with the off-cut.

For the experiment, we made the control AC1 mixture; the off-cuts produced therefrom was added to the similarly prepared AC2 mixture instead of sodium sulphate. The off-cut consumption was $30 \%$ of the mass of cement.

Figure 2 presents the results of the experiment.

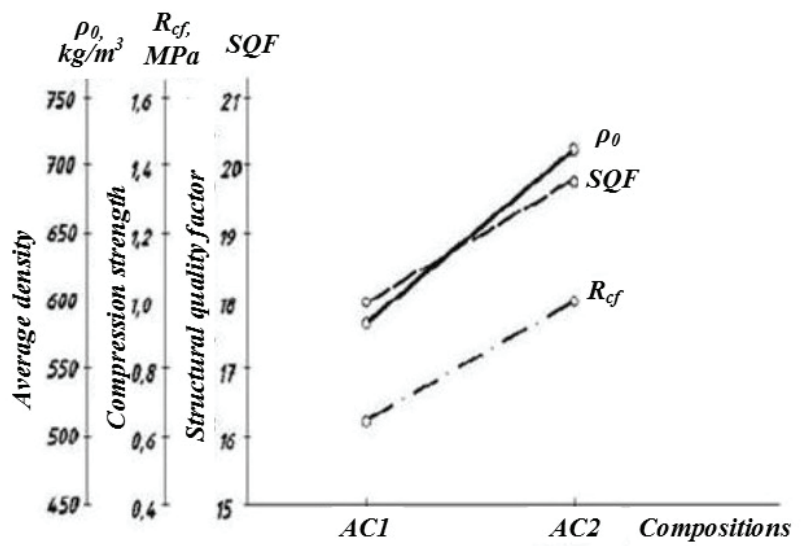

Fig. 2. Test results

Analysis of these data revealed that adding the offcut to the mixture had produced stronger and denser aerated concrete. The structural quality factor of AC1 was $9 \%$ lower than that of the experimental AC2 mixture.
The experiment proved that the off-cut was an efficient additive. This enables both AC waste recycling and reduction of production costs as sodium sulphate is no longer needed.

To evaluate how the off-cut amount in the mixture affects the quality of aerated concrete, we experimented with varying amounts. We produced the control (factory) $\mathrm{AC} 1$ mixture and took off-cuts from there to add it to $\mathrm{AC} 2, \mathrm{AC} 3, \mathrm{AC} 4$, and AC5 mixtures where its mass was respectively $30,10,20,25$ percent of the cement mass.

Figure 3 presents the results of the experiment.

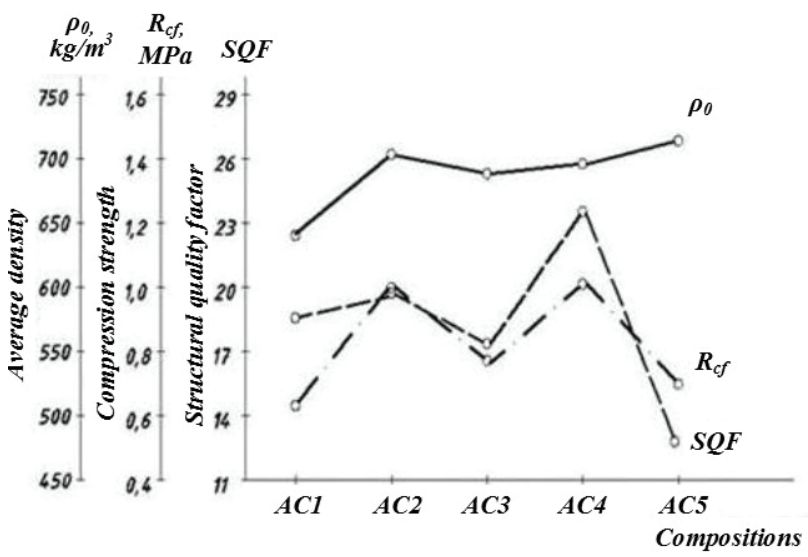

Fig. 3. Test results

Analysis of these data revealed that adding the offcut in the amount equal to $20 \%$ of the cement mass produced stronger aerated concrete. The structural quality factor of AC4 was $20.4 \%$ higher than of $\mathrm{AC} 2$, $31 \%$ higher than that of $\mathrm{AC} 1$.

At the next stage, we decided to find out how efficient is complex sodium-sulphate and off-cut additive when it comes to improving the quality of nonautoclaved aerated concrete.

We experimented to find out the optimal amount of sodium sulphate in the mixture combined with the previously optimized amount of the off-cut. The compositions we studied were as follows: AC1 was the control (factory) mixture with sodium sulphate at $1.54 \%$ of the mass of cement; AC4 was AC1 where sodium sulphate was replaced with the off-cut at $20 \%$ of the cement mass; A1 was $20 \%$ off-cut and $1.23 \%$ sodium cement; A2 was $20 \%$ off-cut and $2.4 \%$ sodium cement; A3 was $20 \%$ off-cut and $3.7 \%$ sodium cement.

Figure 4 presents the results of the experiment. 


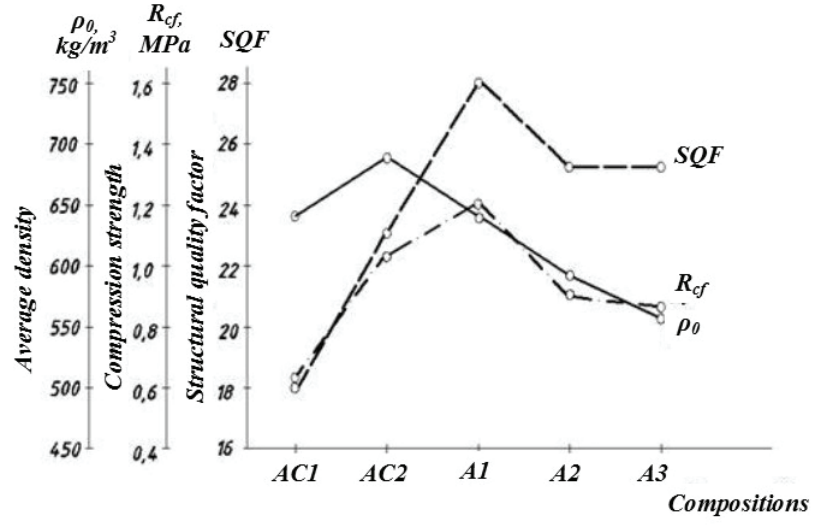

Fig. 4. Test results

Analysis of these data revealed that adding sodium sulphate in the amount of $1.23 \%$ of the cement mass plus the optimum dosage of the off-cut $(20 \%)$ produced the strongest aerated concrete with the highest structural quality factor, i.e. the best sample was A1.

\section{Conclusions}

Thus, based on the literature review and experimental studies, we made a conclusion on how the analyzed composition and technology aspects affect the properties of non-autoclaved AC products.

Adding the off-cut to the mixture had produced stronger and denser aerated concrete. The structural quality factor of $\mathrm{AC} 1$ was $9 \%$ lower than that of the experimental AC2 mixture.

Adding the off-cut in the amount equal to $20 \%$ of the cement mass produced stronger aerated concrete. The structural quality factor of AC4 was $20.4 \%$ higher than of $\mathrm{AC} 2,31 \%$ higher than that of $\mathrm{AC} 1$.

Adding sodium sulphate in the amount of $1.23 \%$ of the cement mass plus the optimum dosage of the off-cut $(20 \%)$ produced the strongest aerated concrete with the highest structural quality factor, i.e. the best sample was A1.

\section{References}

1. N. Narayanan, K. Ramamyrthy, Structure and properties of aerated concrete: a review, Cement \& Concrete Composites, 22, 321-329 (2000)

2. A.I. Shujskij, Optimizacija processov strukturoobrazovanija $i$ povyshenie kachestva gazobetonnyh izdelij, dis. ... kand. teh. nauk (Rostov-na-Donu, 1983)

3. G.Ja. Kunnos, Vibracionnaja tehnologija betona (Izd. lit. Po stroitel'stvu, 1967)

4. A.P. Merkin, Nauchnye $i$ prakticheskie osnovy uluchshenija struktury $i$ svojstv porizovannyh betonov, dis. ... dokt. teh. nauk, (MISI, M, 13-46, 130-139, 1973)

5. A.Ja. Pylaev, A.I. Minas, E.S. Savin, Razrabotka matematicheskoj modeli dlja opredelenija optimal'nyh uslovij vspuchivanija gazobetona, Tez. dokl. II Vsesojuznogo simpoziuma, Reologija betonnyh smesej i ee tehnologicheskie zadachi, Riga, 172-173 (1976)

6. G.P. Saharov, P.V. Kornienko, Obrazovanie optimal'noj struktury jacheistogo betona, Stroitel'nye materialy, 10, 30-33 (1973)

7. A.B. Solodovnik, Kontinual'naja model vspuchivanija zhidkosti s puzyr'kami, dis. ... kand. teh. nauk (Riga, 1969)

8. A.B. Solodovnik, Model' izmenenija poristosti vspuchivajushhejsja dvuhfaznoj sfery, Issledovanija po mehanike stroitel'nyh materialov i konstrukcij, (t. U, Zinatne,1970)

9. K.Je. Gorjajnov, B.O. Atrachev, T.N. Nazarova, Sovershenstvovanie vibroformovanija krupnorazmernyh massivov iz jacheistogo betona, Stroitel'nye materialy, 8 (1978)

10. K. Je. Gorjajnov, S.K. Gorjajnova, Tehnologija teploizoljacionnyh materialov $i$ izdelij, $\mathrm{M}$, Strojizdat, 213-252 (1982)

11. K.Je. Gorjajnov and others, Vlijanie dobavok na process formirovanija struktury $i$ povyshenie kojefficienta kachestva gazosilikata, VNIISTROM, Avtoklavnye silikatnye materialy i konstrukcii. Vjazhushhie materialy, 22 (50), 16-23, (1972)

12. S.A. Krzheminskij, B.B. Kryzhanovskij, S.G. Danilova, Vlijanie tehnologicheskih faktorov na svojstva gazosilikatnyh materialov, $\mathrm{Sb}$. tr. ROSNIIMS, 15 (1959)

13. A.P. Merkin, Napravlennoe izmenenie reologicheskih svojstv jacheistobetonnyh smesej na vseh stadijah proizvodstva polufunkcional'nymi $P A V$, Reologija betonnyh smesej i ee tehnologicheskie zadachi, Tez. dokl. II Vsesojuznogo simpoziuma, Riga, 117-118 (1976)

14. Ju.P. Gorlov, A.P. Merkin, A.A. Ustenko, Tehnologija teploizoljacionnyh materialov (M, Strojizdat, 84-92, 1980)

15. A.Ja. Pylaev, Issledovanie processa vspuchivanija $i$ svojstv gazosilikata, dis. ... kand. tehn. nauk (Rostov-na-Donu, 1977)

16. D.G. Zemcov, S.A. Krzheminskij, G.Ja. Kunnos and others, Jacheistye betony na osnove smesej povyshennoj vjazkosti, VNIISTROM, 20, 14-34 (1971)

17. A.V. Dobrovol'skij, N.P. Sazhnev, Proizvodstvo izdelij iz jacheistyh betonov s primeneniem udarnoj ploshhadki, Promyshlennost' avtoklavnyh materialov i mestnyh vjazhushhih, Ref. inf. VNIIJeSM, 11, 8 (1979)

18. G.V. Krasnova, Proizvodstvo $i$ primenenie $v$ stroitel'stve jacheistyh betonov, Promyshlennost' avtoklavnyh materialov i mestnyh vjazhushhih, Ref. inf. VNIIJeSM, 11, 8, (1981)

19. K.K. Jeskusson and others, Issledovanie tehnologii proizvodstva jacheistogo betona s uluchshennymi stroitel'no-tehnicheskimi svojstvami, 
NIPIsilikatobeton, Proizvodstvo i primenenie silikatnyh betonov, Tallin, 40-49 (1979)

20. V.I. Kalashnikov, Ju.S. Kuznecov, N.I. Makridin. Ispol'zovanie himicheskih dobavok s uchetom tehnologicheskih osobennostej proizvodstva gazobetona, Tez. i dokl. IX Respublikanskoj konferencii Dolgovechnost' konstrukcij iz avtoklavnyh betonov, Part 1, Tallin, NII stroitel'stva Gosstroja SSSR, 151-155 (1981)

21. T.A. Uhova, N.G. Krivickaja, Opyt primenenija kompleksnyh dobavok na osnove superplastifikatorov pri proizvodstve jacheistyh betonov, Tez. dokl. IV Respublikanskoj konferencii Dolgovechnost' konstrukcij iz avtoklavnyh betonov, Part 1, Tallin, NII Stroitel'stva Gosstroja JeSSR, 146-148 (1981)

22. A.P. Merkin, M.I. Zejfman, Osnovnye napravlenija jekonomii toplivno-jenergeticheskih resursov $v$ tehnologii jacheistyh betonov, Povyshenie jeffektivnosti proizvodstva i primenenie industrial'nyh izdelij iz jacheistogo betona $\mathrm{V}$ narodnom hozjajstve, Tez. dokl., Nikolave, 6-8 (1980)

23. A.P. Merkin, Ju.P. Gorlov, M.I. Zejfman, Povyshenie treshhinostojkosti jacheistogo betona za schet formirovanija racional'noj struktury silikatnogo kamnja, Tez. dokl. III Respublikanskoj konferencii, Tallin, 57-61 (1978)

24. A.P. Merkin, M.I. Zejfman, I.B. Udachkin and others, Snizhenie jenergoemkosti proizvodstva $i$ povyshenie kachestva jacheistobetonnyh panelej pri ispol'zovanii peska kompozicionnogo sostava, Stroitel'nye materialy, 3, 4-5 (1981)

25. G.P. Saharov, K.I. Popov, S.S. Bataev, Povyshenie stojkosti jacheistogo betona na grubomolotom peske pri kratkovremennom i dlitel'nom nagruzhenii, Tez. dokl. III Respublikanskoj konferencii Dolgovechnost' konstrukcij iz avtoklavnyh betonov, Tallin, NII stroitel'stva Gosstroja JeSSR, 61-65 (1978)

26. E.M. Chernyshov, A.G. Baranov, A.M. Krohin, Povyshenie kachestva jacheistyh betonov putem uluchshenija ih struktury, Beton i zhelezobeton, 1 (1977)

27. I.B. Udachkin, Ju.V. Gontar', Jeffektivnye sposoby povyshenija vodozashhitnyh svojstv jacheistogo betona, Promyshlennost' avtoklav. mater. i mestnyh vjazhushhih. obzor. inf. VNIIJeSM, 8, 25-30 (1980)

28. Z.V. Shuljupina, N.A. Kozlova, P.R. Taube, Itogi dlitel'nogo ispol'zovanija PAV obrabotki aljuminievoj pudry, Materialy III konferencii po jacheistym betonam, Privolzhskoe knizhnoe iz-vo, Saratov-Penza (1966) 